\title{
THE PERCEPTION OF FIFTH SEMESTER STUDENTS IN LEARNING LISTENING STRATEGIES AT WIDYA GAMA MAHAKAM SAMARINDA UNIVERSITY IN ACADEMIC YEAR 2016/2017
}

\author{
Maimunah Rani Fitri \\ Widya Gama Mahakam Samarinda University \\ mymunahrf@gmail.com
}

\begin{abstract}
The listening skills is viewed as an important skill to master, because from listening we can understand what are people saying, we can get the meaning of every words that speaker talk about, and it is important in process of listening comprehension. The Objective of this research is to find out the perception of fifth semester students of Widya Gama Mahakam Samarinda University in learning listening comprehension. In this research the main theories from Gay (2006) and from (Howitt \& Cramer, 2009). The researcher uses Descriptive Quantitative research. The subject of this study was the fifth semester students of English Department at Widya Gama Mahakam Samarinda University. The researcher uses a questionnaire as an instrument to collect the data, and then representing the data in analysis and concluding the result of analysis. The result of questionnaire showed that students perception toward the strategies in learning listening were 12 students or $171 \%$ very often used Social strategies, 15 students or $171 \%$ often used Affective and Compensation strategies.
\end{abstract}

Keywords: perception, learning, listening strategies

\section{INTRODUCTION}

According to Gilakjani \& Ahmadi (2011) out the four main areas of communication skills called listening, speaking, reading, and writing, listening is the most important of all. Special attention to listening was incorporated into new instructional frameworks, that is, functional language and communicative approaches. According to Nation \& Newton (2009) Listening is the natural precursor to speaking; the early stages of language development in a person's first language (and in naturalistic acquisition of other languages) are dependent on listening. In the view of language learning, listening is the way of learning the language. It gives the learner information from which to build up the knowledge necessary for using the language. When this knowledge is built up, the learner can begin to speak. The listening only period is a time of observation and learning which of provides the basis for the other language skills.

Script Journal Volume 1, Issue 2, October 2016 || P-ISSN 2477-1880 || E-ISSN 2502-6623

http://jurnal.fkip-uwgm.ac.id/index.php/Script 
Human beings are social beings as well as individual, there is a difference between one individual with other. The differences causes why somebody likes an object or something, while others unlike that object or a thing.

According to Devito (2012) Perception is the process by which you become aware of objects, events, and especially people through your senses: sight, smell, taste, touch, and hearing. According to Robbins \& Judge (2013) Perception is a process by which individuals organize and interpret their sensory impressions in order to give meaning to their environment.

Many students who live in Indonesia, they get difficulties in listening English. They often ignore to use English language as a medium of communication due to lack of listening comprehension as mediums when they are studying English. So they could not get the meaning of the words and what about the speaker talks to them, so it is important to use an aid by the teachers in teaching English especially in process of listening comprehension and what the most essential things to be considered.

Due to the problem above the researcher will choose the fifth semester student of English Department in Widya Gama Mahakam University Samarinda, because the researcher has an experience while studied about listening for two years from the first semester until fourth semester in Widya Gama Mahakam Samarinda University, and before the researcher decided to do this research, the researcher have interviewed some students from fifth semester to ask about their opinion in learning listening. The researcher found out that only few students got high score for listening lesson while the researcher study listening and the researcher found that students from fifth semester said learning listening is difficult because the lack of vocabulary and different accents from native speaker.

\section{METHODOLOGY}

\section{Research Design}

The research design in this study used descriptive quantitative research. As a descriptive research, the researcher analyzed and described the student's perception in learning listening comprehension. According to Gay (2006) descriptive research determines and describes the way things are. A high percentage of research studies rely on surveys for data and, as a result, are descriptive in nature. It involves collecting data to answer question about the current status of the subject of the study. Descriptive research is the research on the

Script Journal Volume 1, Issue 2, October 2016 || P-ISSN 2477-1880 || E-ISSN 2502-6623 http://jurnal.fkip-uwgm.ac.id/index.php/Script 
status, attitudes, opinions of individuals, the conditions and procedures, a thought or event that aims to describe by systematically, factually, accurately to solve a problem.

\section{Subject of The Study}

The researcher choose the fifth semester students of Widya Gama Mahakam Samarinda University in Academic Year 2016/2017 because they had been learnt the listening lesson from the first semester until fourth semester. The total number of the students in this semester were 35 students. There were 22 students from morning class and 13 students from afternoon class. The data from the subject was collected in the academic year 2016.

\section{Research Instruments}

In this study, the researcher used questionnaire as an instrument. According to Gay (2010) A questionnaire is a written collection of self-report questions to be answered by a selected group of research participants. The questionnaire was prepared to find out the students' problems and why such problems occurred. Questionnaire is used to collect the factual data. According to Gay (2006) there are two type of questionnaires, a structured item (also called a closed-ended) and an unstructured item (also called an open-ended) questions;

1. A Structured Item (closed-ended)

The questionnaire with a structured item (also called a close-ended item) is any item that asks the respondent to choose among the provided response options (e.g., by circling a letter, checking a list, or numbering preferences).

\section{An Unstructured Item (open-ended)}

The questionnaire with an unstructured item format, in which the respondent has complete freedom of response (questions are posed and the respondent must construct a response), is sometimes defended on the grounds that it permits greater depth of response and insight into the reasons for responses.

In this study, the researcher used a close-ended questionnaire. The questionnaire was used to get some information of students' perception in learning listening comprehension. The questionnaire consisted of several questions which were related to perception about students' strategies in learning listening comprehension, students' perception about the difficulties in learning listening comprehension and lecturer's methods in teaching listening.

Script Journal Volume 1, Issue 2, October 2016 || P-ISSN 2477-1880 || E-ISSN 2502-6623 http://jurnal.fkip-uwgm.ac.id/index.php/Script 


\section{Data Collection Techniques}

To collect the data, the researcher will use the following procedures;

Firstly, the researcher will interview the listening lecturer to ask the data about how many students in fifth semester.

Secondly, the researcher makes the questionnaire that consists of;

a. The strategies in learning listening comprehension;

- Memory strategies

- Cognitive strategies

- Compensation strategies

- Metacognitive strategies

- Affective strategies

- Social strategies

b. The difficulties in learning listening comprehension;

- Unfamiliar vocabulary

- Quality of recorded materials

- Length and speed of listening

- No repeated

- Accents

c. Methods of teaching listening comprehension;

- Jigsaw listening

- Message-taking

- Music and sound effects

- News and other radio genres

- Poetry

- Stories

- Monologues

Thirdly, the researcher gave the questionnaire to the fifth semester students and allocated to them about 35 minutes to answering the questionnaire. The researcher held questionnaire directly to the students. And fourthly, the researcher described the result of the questionnaire.

\section{Data Analysis Techniques}

Data analysis on the students' perception based on the result of the questionnaire was filled by students. To analyze this questionnaire, the researcher used Likert scale. According Script Journal Volume 1, Issue 2, October 2016 || P-ISSN 2477-1880 || E-ISSN 2502-6623 http://jurnal.fkip-uwgm.ac.id/index.php/Script 
to Gay (2006) Likert scale asks an individual to respond to a series of statements by indicating whether he or she strongly agrees (SA), agrees (A), is undecided (U), disagrees (D), or strongly disagrees (SD). The following point values are typically assigned to positive statements: $\mathrm{SA}=5, \mathrm{~A}=4, \mathrm{U}=3, \mathrm{D}=2, \mathrm{SD}=1$. Based on the researcher research, the researcher used Very Often $(\mathrm{VO})=5$ point, Often $(\mathrm{O})=4$ point, Sometime $(\mathrm{S})=3$ point, Rarely $(\mathrm{R})=2$ point, and Very Rarely $(\mathrm{VR})=1$ point as a choice to answer the questionnaire.

To find out the students' perception in learning listening comprehension, the researcher used distribution frequency relative or descriptive analysis technique (percentage) formula. In the table of percentage, the researcher used the (Howitt \& Cramer, 2009) formula;

$$
\text { Percentage Frequency }=\frac{F \times 100}{N}
$$

Where;

$\mathrm{F}=$ Frequency

$\mathrm{N}=$ Number of sample which is observed

\section{FINDING}

Students Perception toward the strategies in learning listening:

\begin{tabular}{|c|c|c|c|c|}
\hline No & Option & Student & Frequency & Percentage (\%) \\
\hline 1 & VO & $\begin{array}{c}1,2,3,6,8,9,16,18, \\
24,28,29,35\end{array}$ & 60 & 171 \\
\hline 2 & O & $\begin{array}{c}4,5,7,11,12,13,15, \\
17,20,25,27,33\end{array}$ & 48 & 137 \\
\hline 3 & S & $\begin{array}{c}10,14,19,21,22, \\
26,30,31,32\end{array}$ & 27 & 77 \\
\hline 4 & R & 23,34 & 4 & 11 \\
\hline 5 & VR & 0 & 0 & 0 \\
\hline
\end{tabular}

Table 4.1 Question 13: Social Strategies

Based on the Table 4.1 above the researcher found from the question number 13 that contains about the strategies in learning listening; "you ask the teacher or your friends to recheck the information which isn't clear"; There were 12 students who answered VO (Very

Script Journal Volume 1, Issue 2, October 2016 || P-ISSN 2477-1880 || E-ISSN 2502-6623 http://jurnal.fkip-uwgm.ac.id/index.php/Script 
Often) with the total was 60 points and the percentage was $171 \%$ that used social strategies in learning listening, 12 students who answered $O$ (Often) with the total was 48 points and the percentage was $137 \%$ that used social strategies in learning listening, 9 students who answered $S$ (Sometime) with the total was 27 points and the percentage was $77 \%$ that used social strategies in learning listening, 2 students who answered $R$ (Rarely) with the total was 4 points and the percentage was $11 \%$ that used social strategies in learning listening.

\begin{tabular}{|c|c|c|c|c|}
\hline No & Option & Student & Frequency & Percentage (\%) \\
\hline 1 & VO & $3,9,18,24,25,32,33$ & 35 & 100 \\
\hline 2 & O & $\begin{array}{c}4,6,10,14,19,20, \\
29,34,45\end{array}$ & 36 & 103 \\
\hline 3 & S & $\begin{array}{c}1,2,5,7,11,12,13,15,16, \\
17,21,22,23,26,28\end{array}$ & 45 & 129 \\
\hline 4 & R & $8,27,30,31$ & 8 & 23 \\
\hline 5 & VR & 0 & 0 & 0 \\
\hline
\end{tabular}

Table 4.2 Question 14: Memory Strategies

Based on the Table 4.2 above the researcher found from the question number 14 that contains about the strategies in learning listening; "you linked the materials with the knowledge that you knew before"; There were 7 students who answered VO (Very Often) with the total was 35 points and the percentage was $100 \%$ that used memory strategies in learning listening, 9 students who answered $O$ (Often) with the total was 36 points and the percentage was $103 \%$ that used memory strategies in learning listening, 15 students who answered $S$ (Sometime) with the total was 45 points and the percentage was $129 \%$ that used memory strategies in learning listening, 4 students who answered $R$ (Rarely) with the total was 8 points and the percentage was $23 \%$ that used memory strategies in learning listening, and there were 0 student who answered VR (Very Rarely).

\begin{tabular}{|c|c|c|c|c|}
\hline No & Option & Student & Frequency & Percentage (\%) \\
\hline 1 & VO & $1,3,18,23,35$ & 25 & 71 \\
\hline 2 & O & $\begin{array}{c}4,6,8,9,16,19,20, \\
24,27,28,29,33\end{array}$ & 48 & 137 \\
\hline
\end{tabular}

Script Journal Volume 1, Issue 2, October 2016 || P-ISSN 2477-1880 || E-ISSN 2502-6623 http://jurnal.fkip-uwgm.ac.id/index.php/Script 


\begin{tabular}{|c|c|c|c|c|}
\hline No & Option & Student & Frequency & Percentage (\%) \\
\hline & & & & \\
3 & $\mathrm{~S}$ & $\begin{array}{c}5,7,10,11,12,13,14,15, \\
17,21,22,26,32,34\end{array}$ & 42 & 120 \\
\hline 4 & R & 2,25 & 4 & 11 \\
\hline 5 & VR & 30,31 & 2 & 6 \\
\hline
\end{tabular}

Table 4.3 Question 15: Cognitive Strategies

Based on the Table 4.3 above the researcher found from the question number 15 that contains about the strategies in learning listening; "you focus on the main ideas, analyzing and draw a conclusion from the material"; There were 5 students who answered VO (Very Often) with the total was 25 points and the percentage was $71 \%$ that used cognitive strategies in learning listening, 12 students who answered $O$ (Often) with the total was 48 points and the percentage wass $137 \%$ that used cognitive strategies in learning listening, 14 students who answered $S$ (Sometime) with the total was 42 points and the percentage was $120 \%$ that used cognitive strategies in learning listening, 2 students who answered $R$ (Rarely) with the total was 4 points and the percentage was $11 \%$ that used cognitive strategies in learning listening, 2 students who answered $V R$ (Very Rarely) with the total was 2 points and the percentage was $6 \%$ that used cognitive strategies in learning listening.

\begin{tabular}{|c|c|c|c|c|}
\hline No & Option & Student & Frequency & Percentage (\%) \\
\hline 1 & VO & $\begin{array}{c}1,2,3,9,17,18,20, \\
23,29,32,33,34\end{array}$ & 60 & 171 \\
\hline 2 & O & $\begin{array}{c}4,5,6,7,8,10,12,15,16, \\
19,25,28,30,31,35\end{array}$ & 60 & 171 \\
\hline 3 & S & $11,13,14,21,22,26$ & 18 & 51 \\
\hline 4 & R & 24,27 & 4 & 11 \\
\hline 5 & VR & 0 & 0 & 0 \\
\hline
\end{tabular}

Table 4.4 Question 16: Affective Strategies

Based on the Table 4.4 above the researcher found from the question number 16 that contains about the strategies in learning listening; "you keep your concentration, keep calm and give positive feedback on yourself in completing the task of listening"; There were 12 students who answered VO (Very Often) with the total was 60 points and the percentage was 
$171 \%$ that used affective strategies in learning listening, 15 students who answered $O$ (Often) with the total was 60 points and the percentage was $171 \%$ that used affective strategies in learning listening, 6 students who answered $S$ (Sometime) with the total was 18 points and the percentage was $51 \%$ that used affective strategies in learning listening, 2 students who answered $R$ (Rarely) with the total was 4 points and the percentage was $11 \%$ that used affective strategies in learning listening, and there were 0 student who answered VR (Very Rarely).

\begin{tabular}{|c|c|c|c|c|}
\hline No & Option & Student & Frequency & Percentage (\%) \\
\hline 1 & VO & $\begin{array}{c}3,4,9,17,18,20,21, \\
22,23,35\end{array}$ & 50 & 143 \\
\hline 2 & O & $\begin{array}{c}1,2,6,8,11,12,13,14, \\
15,25,28,29,30,31,32\end{array}$ & 60 & 171 \\
\hline 3 & S & $\begin{array}{r}5,7,10,16,19,26, \\
27,33,34\end{array}$ & 27 & 77 \\
\hline 4 & R & 24 & 2 & 6 \\
\hline 5 & VR & 0 & 0 & 0 \\
\hline
\end{tabular}

Table 4.5 Question 17: Compensation Strategies

Based on the Table 4.5 above the researcher found from the question number 17 that contains about the strategies in learning listening; "you focus on the instructions and word stress on materials"; There were 10 students who answered VO (Very Often) with the total was 50 points and the percentage was $143 \%$ that used compensation strategies in learning listening, 15 students who answered $O$ (Often) with the total was 60 points and the percentage was $171 \%$ that used compensation strategies in learning listening, 9 students who answer $S$ (Sometime) with the total was 27 points and the percentage was $77 \%$ that used compensation strategies in learning listening, 1 student who answered $R$ (Rarely) with the total was 2 points and the percentage was $6 \%$ that used compensation strategies in learning listening, and there were 0 student who answered VR (Very Rarely).

\begin{tabular}{|c|c|c|c|c|}
\hline No & Option & Student & Frequency & Percentage (\%) \\
\hline 1 & VO & $\begin{array}{c}1,3,4,11,13,17,18, \\
20,21,22,32\end{array}$ & 55 & 157 \\
\hline
\end{tabular}

Script Journal Volume 1, Issue 2, October 2016 || P-ISSN 2477-1880 || E-ISSN 2502-6623 http://jurnal.fkip-uwgm.ac.id/index.php/Script 


\begin{tabular}{|c|c|c|c|c|}
\hline No & Option & Student & Frequency & Percentage (\%) \\
\hline 2 & O & $2,5,6,9,10,12,15$ & 28 & 80 \\
\hline 3 & S & $\begin{array}{c}7,8,14,16,19,23,26,27, \\
28,29,30,31,33,34,35\end{array}$ & 45 & 129 \\
\hline 4 & R & 24 & 2 & 6 \\
\hline 5 & VR & 25 & 1 & 3 \\
\hline
\end{tabular}

Table 4.6 Question 18: Metacognitive Strategies

Based on the Table 4.6 above the researcher found from the question number 18 that contains about the strategies in learning listening; "you analyze the whole of listening material is being given to avoid errors and to make sure you have answered all the tasks that given"; There were 11 students who answered VO (Very Often) with the total was 55 points and the percentage was $157 \%$ that used metacognitive strategies in learning listening, 7 students who answered $O$ (Often) with the total was 28 points and the percentage was $80 \%$ that used metacognitive strategies in learning listening, 15 students who answered $S$ (Sometime) with the total was 45 points and the percentage was $129 \%$ that used metacognitive strategies in learning listening, 1 student who answered $R$ (Rarely) with the total was 2 points and the percentage was $6 \%$ that used metacognitive strategies in learning listening, 1 student who answered VR (Very Rarely) with the total was 1 point and the percentage was $3 \%$ that used metacognitive strategies in learning listening.

\section{DISCUSSION}

Based on first research question "How is the perception of the fifth semester students strategies in learning listening?", to answer this question the researcher used the percentage frequency to measure the students perception with the result shown there are 12 students or $171 \%$ very often used Social strategies, there are 15 students or $171 \%$ very often used Affective strategies, and there are 15 students or $171 \%$ used Compensation strategies in learning listening. The Social strategies from Oxford (1990) theory it helps students to work each other with their friends or the lecturer, in this case to asking for the question (to verification) what isn't clear from the materials. The Affective strategies from Rebecca L. Oxford theory is used by encouraging themselves to keep calm and taking their emotion temperature, as a purpose to keep the concentration in learning listening and in doing the listening task. The Compensation strategies or "guessing intelligently" from Rebecca L. Script Journal Volume 1, Issue 2, October 2016 || P-ISSN 2477-1880 || E-ISSN 2502-6623 http://jurnal.fkip-uwgm.ac.id/index.php/Script 
Oxford theory" is the strategies that used by guess the meaning from the information based on the clues, word stress, word order.

\section{CONCLUSION}

Based on the finding of the study, it drawn some conclusion such as:

Students perception toward the strategies in learning listening, there were 12 students or $171 \%$ that was very often used the social strategies, that helps students to cooperating or work each other with their friends or lecturer. There were 15 students or $171 \%$ that was very often used the affective strategies, that helps students encouraging themselves to keep focus while studied. And there were 15 students or $171 \%$ that was used the compensation strategies, which helps students with guessing the meaning from the information based on the clues, word stress, and word order.

\section{BIBLIOGRAPHY}

Devito, joseph A. (2012). The Interpersonal Communication Book (13th ed.). New York: Pearson Education, Inc.

Gay, L. R. et al. (2006). Education Research (Competencies for Analysis and Applications). New Jersey, USA: Pearson Education, Inc.

Gay, L. R. et al. (2010). Education Research (Competencies for Analysis and Applications). New Jersey, USA: Pearson Education, Inc.

Gilakjani, A. P., \& Ahmadi, M. R. (2011). A Study of Factors Affecting EFL Learners' English Listening Comprehension and the Strategies for Improvement. Journal of Language Teaching and Research, 2(5), 977-988. http://doi.org/10.4304/jltr.2.5.977988

Howitt, D., \& Cramer, D. (2009). Introduction to Statistics in Psychology. Harlow, England: Pearson Prentice Hall.

Nation, I. S. P., \& Newton, J. (2009). Teaching ESL/EFL Listening and Speaking. ESL Applied Linguistics Professional Series (Vol. 15). New York: Routledge. http://doi.org/10.1016/j.system.2009.11.002

Oxford, R. L. (1990). Language Learning Strategies. Boston: Heinle \& Heinle Publisher.

Script Journal Volume 1, Issue 2, October 2016 || P-ISSN 2477-1880 || E-ISSN 2502-6623

http://jurnal.fkip-uwgm.ac.id/index.php/Script 
Robbins, S. P., \& Judge, T. A. (2013). Essentials of Organizational Behaviour (12th ed.). New Jersey, USA: Pearson Education, Inc. 